\title{
Contributions of Slovak Criminology to the Development of Restorative Justice ${ }^{1}$
}

\section{Tomáš Strémy}

Faculty of Law, Comenius University in Bratislava

Šafárikovo nám. č. 6, Bratislava 810 00, Slovak Republic

E-mail: tomas.stremy@flaw.uniba.sk

\section{Gustáv Dianiška}

Faculty of Law, Trnava University in Trnava Hornopotočná 23, Trnava 918 43, Slovak Republic E-mail: gustav@dianiska.sk

\section{Ondrej Hamul'ák}

Faculty of Law, Palacký University Olomouc 17. listopadu 8, Olomouc 771 11, Czech Republic E-mail: ondrej.hamulak@upol.cz

\section{Lukáš Turay}

Faculty of Law, Comenius University in Bratislava Šafárikovo nám. č. 6, Bratislava 810 00, Slovak Republic E-mail: lukas.turay@flaw.uniba.sk

Abstract: Criminology is a relatively young field in Slovakia. Insight into its short history suggests that it was primarily developed by the efforts of individual personalities of several generations. Criminology in its modern sense can be dated to the 1960s. In Czechoslovakia, after 1948, the discipline

1 This work was supported by the Agency for Research and Development under the contract no. APVV-15-0740. 
of criminology was considered unnecessary. Crime was seen as a relic of the capitalist class society and it was expected to disappear after socialism was established. However, it turned out that ideological rhetoric does not work and that crime is a phenomenon present in every society. After 1989, when the Velvet Revolution opened the door to the world, hopes for its institutional development increased. However, these desires were not completely fulfilled. Slovakia still does not have a specialized institute of criminology, but the discipline has taken hold in some Slovak universities. A few books and monographs were published and several research projects were implemented by Slovak criminologists. Professor Vojtech Hatala, an excellent criminal lawyer, substantial public and academic figure, has played a special role in the history of Slovak criminology. As a dissident, he wrote for himself only and it is a great pleasure that we have found his contribution and published it in 2011. Professor Hatala, who was recognized at the time when retributive justice was predominant, analyses the phenomena that are characteristic of modern-day restorative justice. He identifies the causal link between juvenile crime, including recurrence, and the impact of the offender's family environment, in addition to the impact of institutions, such as prisons and reformatories, whose main purpose is partial or total isolation from the normal social environment. Here arises the question of whether we can carry out a successful social reintegration under these circumstances.

Keywords: community cooperation, correction of an offender, criminology, restorative justice, retributive justice, sanctioning

\section{Introduction}

Restorative justice has many sympathizers among criminologists (Gavrielides, 2008; Morris, 2002; Shapland, 2006), judges and professionals. Although we have some of its proponents in Slovakia, the attention paid is scarce and the use of its methods is still insufficient. To help fill the gap, this paper summarizes the main features of restorative justice and its advantages over retributive justice. With a brief insight into the history of criminology in Czechoslovakia, we get to the study of Professor Vojtech Hatala, which examines cases of juvenile criminals from the 1970s and 1980s. Our attention is focused on the causal link between juvenile crime and the influence of the offender's family environment, and also on the impact of partial or total isolation from the natural social 
environment. We compare the purely punitive and offender-isolating sanctions (retributive justice) with sentences the purpose of which is to correct the offender and reintegrate him back into society (restorative justice). The results of our research indicate that partial or total isolation of the offender from his or her normal social environment is not the only and the best option in the field of correction of an offender (Ščerba, 2013), but the dialogue between victims and criminals should be provided and the whole society should cooperate to reintegrate the offender and help him in the process of understanding and fulfilling his obligations (Strang, 2002).

\section{Criminology and crime in the Slovak Republic in the second half of the 2oth century}

Criminology in Slovakia is not a cakewalk. This is a relatively young field that has not been paid sufficient attention and care for the development of its foundations. Insight into the short history of this field in Slovakia suggests that it has been primarily the efforts of individual criminologists of several generations. Its modern origin can be dated to the 1960s. It should, however, be noted that these foundations were formed in the state shared by Czechs and Slovaks.

After 1948, the science of criminology was considered unnecessary in Czechoslovakia. Crime was seen as a relic of the capitalist class society, as well as a result of class struggle. Considering this view, it was believed that by establishing a socialist society, crime would gradually disappear. It turned out, however, that the ideological rhetoric did not work and that crime is a phenomenon that accompanies every social order. At this time, criminology understandably already existed as a scientific discipline.

In the 1960s, the centre of criminology in Czechoslovakia was the Criminological Research Institute, which actively began reporting and publishing the work of professionals from disciplines related to crime in Czechoslovakia. Among these pioneers were some Slovak scientists and educators. The criminological focus of these professionals was on two sources (jurisprudence and a sociological analysis of social processes). A little later psychological perception problems were added to these resources.

The mapping and analysis of the history of criminology in Slovakia are still in their infancy. Certainly, as is the case in Czech history, it was also unknown in 
the first half of the 20th century and also the final years of the 19th century and was discovered by a Slovak Jozef Prušák, a lawyer, judge and professor of criminal law at Charles University, who introduced the term "criminal science" in 1890 (Otto, 1900; Prušák, 1904).

In 1968, the textbook on criminology was published in the Slovak Republic by Ladislav Schubert and Gabriela Nikšová (1986). The authors expressed their (at the time rather bold) preliminary observation that crime is not only an undesirable phenomenon, but it is a phenomenon that accompanies human society and will be the subject of consideration, diagnoses, and proposals for its elimination for a long time. The authors define criminology as the sociolegal approach to crime and delinquency. They emphasize that it is a separate system of knowledge to solve a crime, identify its status, structure, dynamics, conditions, causes, the personality of the offender and the victim-mainly his role at the beginning of committing a crime.

To include the subject of purposeful activity aimed at preventing crimes and offenses, a significant aspect discussed in the textbook is methodology, which at this time started the gradual process of developing criminology from criminal law. From the auxiliary science of criminal law, criminology began to form as a science with a real theoretical basis, particularly methodological equipment, and the ability to use the methods of other sciences and contribute significantly to prevention activities.

Despite these positive signals, criminological approach at that time in Slovakia (and in socialist countries in general) was delayed, compared to democratic developed countries. To elaborate on the model of socialism, oriented criminology and theoretical directions in Western criminology were strongly criticized. The contradictory and dynamic social processes, as well as more intensive penetration of criminological information from abroad strengthened the views of Slovak criminologists that it is illusory to think that crime would be eliminated, for example, by raising the material and cultural level of a society. It has also been argued that the dogmatic application of scientific communism in Slovak criminology is, in fact, an escape from reality.

Professor Gabriela Nikšová was and continues to be among the important Slovak figures who have influenced the development of criminology in Czechoslovakia. She is responsible for eliminating the ideological aspect from criminology and strengthening its technical side. The 1970 dictionary of foreign words defines criminology as follows: "Criminology is a professional science whose object is 
the study of crime and its causes, and whose practical purpose is to find the most effective means for fighting crime as a harmful social phenomenon" (ك̌aling, Šaligová \& Peter, 1970).

Hopes were high for the development of Slovakia's criminology after 1989, when doors to the world were fully opened and its institutional development was expected to increase. Nothing prevented, as it seemed, the development of full-scale research activities, based primarily on practical needs. So far, however, these hopes have not fully materialized. Slovakia still does not have a specialized institute of criminology. Criminology, however, has taken hold in some Slovakia's universities. Academic departments develop ${ }^{2}$ and implement criminology, not only as an important subject of the curriculum but also in their research and development activities. Currently, a number of books and monographs have been published and several research projects have been carried out on criminology in Slovakia (Holcr et al., 2008; Lubelcová, 2009; Turayová et al., 1999). Often, however, the research results have met little interest from the part of the governing bodies, as well as the general public, which is influenced by the distorted and tendentious presentation of crime in the mass media. In this regard we were struck by a heretical thought: Each system, when it becomes substantial, takes great interest in empirical opposition, as well as the suggestions of science, which seeks to exclude ideological interests.

We would like to point out one fact which confirms the above words. Even after more than a quarter of a century, the Slovak Republic, unfortunately, had a minimum representation (three teachers from the Faculty of Law-Strémy, Jalč, and Vráblová) at the World Congress of Criminology, held every four years (e.g., on 11-13 August 2014 in Monterrey, Mexico), and the annual Conference of the European Society of Criminology (e.g., on 11-13 November 2014 in Prague), at which lectures were given by over 800 active contributors. This fact only proves that even after 27 years, Slovakia's criminology is not well represented at international congresses and conferences, and it is not only the problem of language proficiency. ${ }^{3}$

2 Department of Criminal Law, Criminology and Criminalistics, Faculty of Law, Comenius University in Bratislava; Department of Criminal Law and Criminology, Faculty of Law, Trnava University.

3 Some Slovak criminologists (Dianiška, Stremy) attempted to propose the founding of an institute of criminology in the Slovak Republic, and concretize at workshops or committees the codification of criminal law but almost always got the same answer: "At present we do not have enough means to establish an institute of criminology in the Slovak Republic." 


\section{Thoughts about the needs of restorative justice in the work of Vojtech Hatala}

Professor Vojtech Hatala (17 April 1930, Trnava-21 November 1985, Bratislava), excellent criminal lawyer and a leading public and academic figure, has played a special role in the history of Slovak criminology. His criminological studies have been written mainly as samizdat, or shadow literature, at the times when Professor Hatala was a dissident suppressed by the totalitarian regime. He wrote mostly privately without public dissemination of his works. It is a true blessing for the Slovakian criminology and its development that his works were discovered and published in 2011 (Hatala, 2011).

Hatala focused on the issue of youth crime. In studies written in 1973-1985, he attempted to analyse the problem of youth engaged in legal awareness, group, violent and moral crime. Professor Hatala investigated the causes of youth crime, issues of crime prevention, and devoted considerable attention to criminal recidivism. His vibrant pioneering approach is underlined by the fact that all of the mentioned topics form the frontline of current criminological research and scholarly writings (Barry, 2016, pp. 91-106; Farral, Bottoms \& Shapland, 2010, pp. 546-570). In his research of the issues he applied systematic methodological approach on three interdependent levels: (1) issues as a whole (e.g., the entire breadth of the concept of juvenile delinquency); (2) identifying phenomena specific to the conceptual level (as a kind of phenomenon); and (3) investigationspecific unique phenomena (case report).

For the authors of this paper it is particularly noteworthy that Professor Hatala was active at the time when retributive justice highlighted and analysed the phenomena that are characteristic of today's restorative justice (Hatala, 1968; $1981 ; 1975 ; 1977)$. Below are some of his views, which are characterized by a multidisciplinary approach, taking into account psychological, sociological, victimological, penological and criminal aspects (Hatala, 1968; 1981). These observations were mostly made in the context of the analysis of recidivism in juvenile crime.

Here Hatala criticizes the rigidity of criminological knowledge and emphasizes the need to evaluate the noticed phenomenology of this criminal phenomenon. At the same time he states his opinion on various types of crime which are typical of juvenile offenders: predominance of property crime, followed by attacks on life and health (violent crime), and, to a lesser extent, rioting and parasitism. 
This trend has continued to have effect until this day. The structure of juvenile criminal recidivists, Hatala notes, is no different from the phenomenology of juvenile crime as a whole (first-time offenders-repeat offenders). Hatala also comments on the available phenomenological sources, arguing that the structure of crimes committed by juvenile recidivists is no different from that of criminal offenses committed by adult recidivists. He was concerned about the increasing rate of juvenile recidivism, which has been confirmed as a fact in the present day.

Hatala describes the etiological aspect of juvenile recidivism, which is still a question of worldwide importance (Lay, 2005, pp. 39-66). The causes of differentiation include factors that are directly connected with the recurrence of juvenile crime, as well as those addressed by the task. At the same time, the results of many studies show a correlation of juvenile recidivism with certain variations in development already in the subject's adolescence. A specific manifestation of these deviations are committing crimes in which a person is charged with criminal irresponsibility, as well as supporting crimes committed by parents of children. It also identifies the causal link between juvenile crime, including recurrence, and the impact of family environment on the offender (Jeong, McGarrel \& Hipple, 2012). In addition to the impact of family, the operation of such institutions, such as prisons and reformatories, is indicated. Hatala also points out that correctional partial or total isolation of the offender from the normal social environment is common for both institutions. He also argued whether successful social reintegration is possible in these circumstances. In his search for causes, Hatala forgot that even law constitutes a serious external determinant of the behaviour of juvenile offenders. Hatala highlighted the negative impact of improper use of law enforcement. His criticism focuses mainly on the process of law in criminal proceedings (weakening of the principle of the presumption of innocence, incomplete findings of fact, and the like).

What are the prospects for redress of young repeat offenders and crime prevention? Hatala asks this question at the end of his reflections on juvenile crime recidivism. According to him and in concert with other professionals, the following major aspects have to be considered in order to eliminate recurrence: proper punishment area; rules and method of implementation of the death penalty; and quality of activity after being released from prison (Robinson $\&$ Shapland, 2008).

Hatala compares this aspect with judicial practice. In this connection he criticizes the practice of extending penalties on repeat offenders. Sentences involving long-term imprisonment have not been considered properly. Hatala suggests 
the adoption of new methods in the future which would reflect the individuality of the offender. He adds that the length of the sentence does not matter and in the future only the conceptual, goal-oriented, and intensive use of sanctions will make a difference.

He introduced precautionary measures, for example, therapy as alternative punishment. The principles of punishment do not involve only retribution but also correction of the offender, which is important for preventing the committing of future crimes (Ščerba, 2013). Hatala even held the view that the corrective principle of recompense is inherently incompatible. According to him, this means that reparation cannot lead to actual rehabilitation-at best, it can lead to deterrence. Hatala argues that even the implementation of the principle of prison experience has value, and the application of these values would deepen its effectiveness. As a starting point for more efficiency, Hatala sees the issue of correctional dialogue with young repeat offenders, their knowledge and individual approach (Rossner, 2011; Wikström \& Treiber, 2007). This refers to the requirements of the Hague Congress of $1950,{ }^{4}$ which recommended grouping of prisoners by age, sex, relapse, mental status, and the creation of specific working groups. Creating groups on the basis of certain similarities allows more informal influences to open up prison communities that are grouped on the basis of the ideology of good cellmates.

Hatala argued that the most negative aspects of imprisonment were "gathering criminally minded people in one relatively small place, and moreover, closed space" and that "efforts of re-socialization are performed in a place of confined conditions of social isolation" (Hatala, 2001). He also referred to the part of the targeted behaviour of prisoners in accordance with prison rules, motivation which is caused by the possibility of early release. Hatala argued that a fundamental requirement of the success of the sentence was "a coherent, comprehensive concept of personalized action on inmates" (Hatala, 2001). The concept should include the right mix of educators and the convicted, also the structure and qualifications of the prison staff, as well as the optimal prison regime. Interesting is his proposal for the preparation of a real long-term plan for the prisoner after his release, strengthening prisoners' social, legal and moral awareness and preparation for integration in civic and professional life. In terms of the return of a juvenile to civic life, Hatala highlights the important role of community (healthy group) in a person's re-socialization. This is similar to the idea of John Braithwaite, who

4 The Twelfth International Penal and Penitentiary Congress met at The Hague on 14th of August 1950 . 
later introduced the concept of reintegrative shaming in criminological theory and, like Hatala, emphasized the role of community in the social reintegration of the offender (Braithwaite, 1989; 2008; 2002). If a group (community) is able and willing to tell the offender that he had acted improperly, thus participating in correcting, the educational effect of punishment is enhanced by this informal, very effective dimension.

The most important aspect in the code of post-prison care of juvenile repeat offenders is the duty of institutional and organizational arrangements, including the creation of a central coordinating body. In post-prison care, professional assistance by a staff of professionals should only play a complementary role. In the second place, but one with a legal obligation, is an element of social control for conditional release. The importance of this element lies in the fact that many "quick" relapses occur at this time (Hayes et al., 2014). Hatala not only highlighted the general purposeful (external) behaviour of prisoners applying for parole but it is erroneously associated with practice. Criminogenic element of parole that is not based on substance is an institutional, though faulty, practice. Despite these facts, Hatala does not deny that parole of juvenile offenders is an important educational resource. All the above observations, reflections, and recommendations are considered important historical contribution to the ongoing development of restorative justice in Slovakia and the introduction and increased use of alternative punishments (Thijs at al., 2015).

\section{The main features of restorative justice}

The doctrine and good practice of restorative justice is built on several elements, the key points of which are the following:

- Compensating the victims and addressing their needs;

- Preparation of offenders and holding them accountable to restore the damage; and, subsequently,

- The involvement of victims and offenders and the society into this process (Zehr, 2002, p. 74).

The main features of restorative justice are the following:

- Focusing on consequences of the crime more than on the fact that the law was breached; 
- Showing the same concern and resolution towards the victim and the offender that involves the participation of both in the justice process; working on the compensation of victims, strengthening these in addressing the needs as they perceive them;

- Supporting and encouraging offenders in understanding and acceptance of obligations, making them fulfil their obligations;

- Recognizing obligations that might be more difficult for the offender and should not be seen as something harmful and that should be, at the same time, attainable; providing an opportunity for dialogue, direct or indirect, between the victim and the offender;

- Finding meaningful ways how to involve the society in the process;

- Supporting cooperation and reintegration of victims and offender rather than to apply coercion and isolation; paying attention to thoughtless consequences of one's own acts; and

- Respecting all parties— the victim, the offender and the society.

(Beck, Kropf \& Blume Leonard, 2010; Dignan et al., 2007)

In the opinion of Conrad Brunk, the theoretical and philosophical scopes of the terms restorative justice and retributive justice are not opposites, as some people might assume (Brunk, 2001, pp. 31-56). Restorative justice introduces new elements into traditional criminal justice, such as mediation between the offender and the victim, group extrajudicial hearings of minor offences of juvenile delinquents (the so-called family group conferences) and also pointing out the compensation of harm caused to the victim (Scheinost, 2003, p. 4). At the same time, restorative justice represents a traditional form of criminal justice that focuses mainly on punishing the offender but also on the restoration of previous conditions.

The characteristic feature of both theories is the compensation of damage to the victim. The difference between both theories arises in application of specific settlement of affairs.

The retributive theory means that the punishment is deserved, which in practice is often counter-productive for the victims and the offenders. On the other hand, the restorative justice theory shows that addressing the needs and harms done to the victim is needed in combination with an active effort to support the offender to accept responsibility for the committed crimes and focus on the causes of his behaviour (Zehr, 2002). 
The differences between restorative and retributive justice, according to Howard Zehr (2002), are given in Table 1.

Table 1. Differences between restorative justice and retributive justice by Howard Zehr

\begin{tabular}{|l|l|}
\hline Restorative Justice: & Retributive Justice: \\
\hline $\begin{array}{l}\text { The crime presents a disruption of } \\
\text { personal and interpersonal relations. }\end{array}$ & $\begin{array}{l}\text { The crime presents a disruption of } \\
\text { law and the interests of state. }\end{array}$ \\
\hline The disruption leads to obligations. & The disruption leads to guilt. \\
\hline $\begin{array}{l}\text { In the restoration process, justice } \\
\text { involves: victims, offenders and the } \\
\text { society. }\end{array}$ & $\begin{array}{l}\text { Justice requires the state to decide } \\
\text { on the guilt and impose punishment. }\end{array}$ \\
\hline $\begin{array}{l}\text { Focus: needs of the victim and } \\
\text { offenders and responsibility for } \\
\text { restoration of damage. }\end{array}$ & $\begin{array}{l}\text { Focus: the offender should get what } \\
\text { he deserves }\end{array}$ \\
\hline
\end{tabular}

On the basis of these differences, Zehr (2002) posed three questions of how to see the committed crime from the perspective of restorative or retributive concept (Table 2).

Table 2. Zehr's three questions of how to see the committed crime from the perspective of restorative or retributive concept

\begin{tabular}{|l|l|}
\hline Restorative justice: & Retributive justice: \\
\hline Who has been hurt? & What law has been breached? \\
\hline What are their needs? & Who did it? \\
\hline Whose obligations are these? & What do they deserve? \\
\hline
\end{tabular}

The retribution theory believes that the harm caused to the victim will be remedied, but it is often counter-productive in practice for the victim and the offender. On the other hand, the restorative theory justice argues, or more precisely, really advocates for becoming aware of the damage the offender caused to the victim together with the effort to encourage him to assume responsibility for the offence. At the same time, restorative justice has the potential to transform the lives of the offender and the victim in a positive way. (Zehr, 2002) 
Tomáš Strémy, Gustav Dianiška,

Ondrej Hamulák, Lukáš Turay

Proponents of restorative justice have a different opinion than the traditional reformers of criminal law (Zernova, 2007). Before they see victims, they also see offenders and how to get them back into the society, i.e. how to reintegrate them. Naturally, the victims are people that were "hurt" in the course of the offence but at the same time they should be able to empathize with the offender as a person who could be punished in another way than by a sentence of imprisonment. The restorative justice focuses, inter alia, on the return of the victim into the society (Clear, 2008).

\section{Juvenile crimes in the Slovak Republic (at present)}

One of the most important part of Hatala's work is linked to juvenile crimes. The legal system of the Slovak Republic does not contain a specific act concerning the punishment of juveniles. This issue is covered by the Criminal Code and the Criminal Procedure Code. In the framework of the Criminal Code this issue is dealt with in Chapter 4 of the General Part. According to the Slovak law, a person who at the time of committing an offense has reached the age of 14 and has not reached the age of 18 is considered a juvenile.

An offender is criminally liable when he has reached the age of 14 at the time of committing the crime. The criminal offender committing sexual abuse (under $\left.\$ 201^{5}\right)$ is not criminally liable if at the time of committing the crime the offender had not reached the age of 15 .

A juvenile younger than 15 years of age, who at the time of committing an offense has not attained a level of rational and moral maturity to recognize the unlawfulness of his/her actions or to control his/her actions is not criminally responsible for this act. The purpose of punishing juveniles is primarily to educate them to be good citizens, while the punishment should act to prevent unlawful acts and adequately protect the society; the imposed punishment should at the same time lead to the restoration of disturbed social relations and to the integration of the juvenile into the family and the social environment.

5 A person who performs sexual intercourse with a person under the age of 15 or whoever sexually abuses such a person shall be punished by a prison sentence of three to ten years. 
Table 3. The proportion of juvenile crimes to total crimes in the Slovak Republic for 2011-2018.

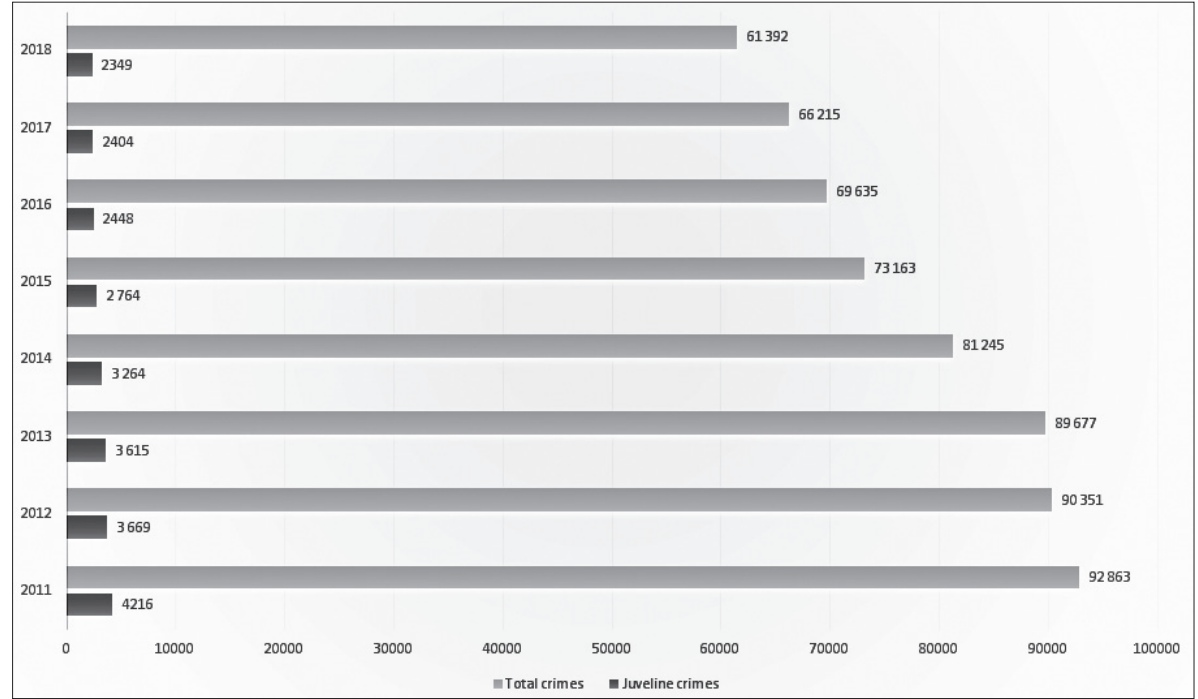

Source: Ministry of Interior of the Slovak Republic, n.d.

Table 3 shows that we are currently witnessing a decrease in total crime in the Slovak Republic, which can also be stated in relation to juvenile delinquency. For example, in 2013, total crime in the Slovak Republic was at 89,677 ascertained crimes, of which 3,615 were committed by juvenile offenders, representing a $4.0311 \%$ share. In 2017, a total of 66,215 crimes were detected in the Slovak Republic, of which $3.6306 \%(2,404)$ were committed by juvenile offenders. In 2018 , the number of crimes detected was 61,392 , of which the share of $3.8262 \%$ (2,349 crimes) constituted juvenile crime. Although the overall crime rate in the Slovak Republic is decreasing, it can be concluded that the percentage of juvenile offenders is on the rise.

\section{Conclusions}

The attempt to describe the evolution of criminology in Czechoslovakia has led us to important works of experts who contributed to the development of this branch of science. Professor Hatala's study showed the causal nexus between isolation of criminals and their lack of progress in understanding the consequences of their actions and in their reintegration into the society, as well 
as its inadequate manner of satisfying the victims. Therefore, justice defined by a state's decision on guilt and punishment is not the best way to strengthen the social, legal and moral consciousness of offenders and does not prepare them for inclusion in the civic and professional life after serving sentence.

In this article, we focused on the development of criminology in former Czechoslovakia, and Slovakia as one of the successor countries. We tried to analyse the work of Gabriela Nikšova and Ladislav Schubert, and predominantly the works and doctrinal influence of Vojtech Hatala. Even though criminology has (especially in the person of Hatala) very good grounds, the developments in the last decades have not been as robust and straightforward. Hatala suggests that in the future we should use new methods which would reflect the individuality of the offender. He adds that no matter the length of the sentence, mainly conceptual, goal-oriented, intensive use of sanctions make a difference. Punishment should not only be about revenge, but should also seek correction of the offender. Hatala's proposal of a long-term plan for a prisoner after his/ her release, strengthening his/her social, legal and moral consciousness and preparation for inclusion in civic and professional life, where he highlights the important role of community (healthy group) for the prisoner's re-socialization, is very interesting and progressive and was considered an important historical contribution to the development of restorative justice in Slovakia. Restorative justice requires focusing on the consequences of a crime rather than on the fact that the law had been breached; working on the compensation of the loss suffered by the victims; supporting offenders in the process of understanding and fulfilling their obligations; providing an opportunity for dialogue between the victims and the offenders; and involving the society into the process of reintegrating the offender in normal life. Restorative justice represents a traditional form of criminal justice that focuses on the needs of the victims and the offenders and responsibility for restoration of damage, while retributive justice is defined by a state's decision on guilt and punishment. Proponents of restorative justice, besides seeing victims, also see offenders and how to win them back to the society and how to reintegrate them. As we have pointed out in our paper, one of the most critical problems is the gap in the institutional background for solid research. Even after more than a quarter of a century following the so-called Velvet Revolution, the establishment of an institute of criminology in the Slovak Republic seems to remain a long and exhausting task. 


\section{References}

Barry, M. (2016), 'On the cusp of recognition: using critical theory to promote desistance among young offenders,' Theoretical Criminology, vol. 20, pp. 91-106. https://doi.org/10.1177/1362480615586613

Beck, E.; Kropf, N. P. \& Blume Leonard, P. (2010), Social Work and Restorative Justice: Skills for Dialogue, Peacemaking, and Reconciliation, Oxford: Oxford University Press. https://doi.org/10.1093/acprof:oso/9780195394641.001.0001

Braithwaite, J. (1989), Crime, Shame and Reintegration, Cambridge: Cambridge University Press. https://doi.org/10.1017/CBO9780511804618

Braithwaite, J. (2002), Restorative Justice and Responsive Regulation, New York: Oxford University Press.

Braithwaite, J. (2008), Regulatory Capitalism: How it Works, Ideas for Making it Work Better, Cheltenham: Edward Elgar.

Brunk, C. (2001), 'Restorative justice and the philosophical theories of criminal punishment,' in Michael L. Hadley (ed.) The Spiritual Roots of Restorative Justice, Albany: State University of New York Press, pp. 31-56.

Clear, T. R. (2008), 'Community justice versus restorative justice: contrasts in family of value,' in D. Sullivan \& L. Tifft (eds.) Handbook of Restorative Justice - A Global Perspective, London: Routledge, pp. 463-471.

Dignan, J. et al. (2007), 'Staging restorative justice encounters against a criminal justice backdrop: a dramaturgical analysis,' Criminology and Criminal Justice, vol. 7, no. 1, pp. 5-32. https://doi.org/10.1177/1748895807072474

Farral, S.; Bottoms, A. \& Shapland, J. (2010), 'Social structures and desistance from crime,' European Journal of Criminology, vol. 7, no. 6, pp. 546-570. https://doi. org/10.1177/1477370810376574

Gavrielides, T. (2008), 'Restorative justice-the perplexing concept: conceptual fault-lines and power battles within the restorative justice movement,' Criminology and Criminal Justice, vol. 8, no. 2, pp. 165-183. https://doi.org/10.1177/1748895808088993

Hatala, V. (1961), Zavinenie v československom socialistickom trestnom práve [Concept of fault in Czechoslovakia's socialist criminal law], Bratislava: SAV.

Hatala, V. (1968), Motiv a trestný čin [The motive and criminal offence], Bratislava: SAV.

Hatala, V. (1975), Právne vedomie a juvenilná kriminalita [Legal awareness and juvenile criminality], Bratislava: VÚDPaP.

Hatala, V. (1977), Recidiva a juvenilná kriminalita [Recidivism and juvenile delinquency], Bratislava: VÚDPaP.

Hatala, V. (1981), Násilná kriminalita mládeže [Violent criminality of the youth], Bratislava: VÚDPaP. 
Tomáš Strémy, Gustav Dianiška,

Ondrej Hamulák, Lukáš Turay

Hatala, V. (2011), Kriminologické štúdie: Výber z diela 1973-1985 [Criminological studies: 1973-1985], Bratislava: Kaligram.

Hayes, H.; McGee, T. R.; Punter, H. \& Cerruto, M. J. (2014), 'Agreements in restorative justice conferences: exploring the implications of agreements for post-conference offending behaviour,' British Journal of Criminology, vol. 54, no. 1, pp. 109-127. https://doi.org/10.1093/bjc/azt056

Holcr, K. et al. (2008), Kriminológia [Crominology], Bratislava: Iura Edition.

Jeong, S.; McGarrell, E. F. \& Hipple, N. K. (2012), 'Long-term impact of family group conferences on the re-offending: the Indianapolis restorative justice experiment,' Journal of Experimental Criminology, vol. 8, no. 4, pp. 369-385. https://doi.org/10.1007/s11292-012-9158-8

Kurilovská, L. \& Lenhartová, K. (2013), 'EÚ ako otvorená cesta restoratívnej justície' [EU as an open way to restorative justice], Právny obzor [Legal Horizons: Journal of the Institute of Law and State of the Slovak Academy of Science], vol. 96, no. 3, pp. 263-270.

Lay, B.; Ihle, W.; Esser, G. \& Schmidt, M. H. (2005), 'Juvenile-episodic, continued or adult-onset deliquency? Risk conditions analysed in a cohort of children followed up to the age of 25 years,' European Journal of Criminology, vol. 2, pp. 39-66. https://doi.org/10.1177/1477370805048629

Lubelcová, G. (2009), Kriminalita ako spoločenský fenomén: Úvod do sociologicky orientovanej kriminológie [Criminality as a social phenomenon: introduction to the sociologically oriented criminology], Bratislava: SAV

Madliak, J. (1998), Kriminológia [Criminology], Košice: Atom Computers.

Ministry of Interior of the Slovak Republic (n.d.), Statistika kriminality $v$ Slovenskej republike [Statistics of criminality in the Slovak Republic]. Retrieved from https:// www.minv.sk/?statistika-kriminality-v-slovenskej-republike-xml [accessed Mar 2019]

Morris, A. (2002), 'Critiquing the Critics: A brief response to critics of restorative justice,' British Journal of Criminology, vol. 42, no. 3, pp. 596-615. https://doi.org/10.1093/bjc/42.3.596

Ottův slovník naučný (1900), Patnáctý díl [Scientific dictionary, vol. 15], Praha: J. Otto.

Prušák, J. (1904), Kriminelní noetika [Criminal epistemiology], Praha: Bursík \& Kohout.

Robinson, G. \& Shapland, J. (2008), 'Reducing recidivism, a task for restorative justice?' British Journal of Criminology, vol. 48, no. 3, pp. 337-358. https://doi. org/10.1093/bjc/azn002

Rossner, M. (2011), 'Emotions and interaction ritual. A micro analysis of restorative justice,' British Journal of Criminology, vol. 51, no. 1, pp. 95-119. https://doi. org/10.1093/bjc/azq075 
Šaling, S.; Šalingová, M. \& Peter, O. (1970), Slovník cudzich slov [Dictionary of foreign words], 3rd ed., Bratislava: SPN.

Ščerba, F. (2013), 'The use of alternative measures in the Czech Republic,' Baltic Journal of Law and Politics, vol. 6, no. 1, pp. 89-105. https://doi.org/10.2478/bjlp-2013-0005

Scheinost, M. (2003), 'Úvodní poznámka' [Introduction], in Z. Karabec (ed.) Restorativni justice. Sbornik príspevku a dokumentì, Praha: Institut pro kriminologii a sociální prevenci, p. 4.

Schubert, L. \& Nikšová, G. (1986), Kriminológia: Všeobecná časṫ [Criminology: the general theory], Bratislava: Comenius University.

Shapland, J. et al. (2006), 'Situating restorative justice within criminal justice,' Theoretical Criminology, vol. 10, no. 4, pp. 505-532. https://doi.org/10.1177/1362480606068876

Strang, H. (2002), Repair or Revenge: Victims and Restorative Justice, Oxford: Clarendon Press.

Thijs, P. E.; van Dijk, I. K.; Stoof, R. \& Notten, N. (2015), 'Adolescent problem behaviour: the gender gap in European perspective,' European Journal of Criminology, vol. 12, no. 5, pp. 598-615. https://doi.org/10.1177/1477370815578195

Turayová, Y. et al. (1999), Vybrané kapitoly z kriminológie [Selected issues from criminology], Bratislava: PF UK.

Van Ginneken, E. \& Hayes, D. (2016), “'Just” punishment? Offenders' views on the meaning and severity of punishment,' Criminology and Criminal Justice, vol. 16, no. 1, pp. 1-17. https://doi.org/10.1177/1748895816654204

Wikström, P.-O. H. \& Treiber, K. (2007), 'The role of self-control in crime causation. Beyond Gottfredson and Hirschi's general theory of crime,' European Journal of Criminology, vol.4, no. 2, pp. 237-264. https://doi.org/10.1177/1477370807074858

Zehr, H. (2002), The Little Book of Restorative Justice, Intercourse, PA: Good Books.

Zernova, M. (2007), 'Aspirations of restorative justice proponents and experiences of participants in family group conferences,' British Journal of Criminology, vol. 47, no. 3, pp. 491-509. https://doi.org/10.1093/bjc/azl063

Tomáš Strémy is an associate professor in the field of criminal law. He works in the Department of Criminal Law and Criminology, where he lectures criminal law and criminology. He is an active participant in the annual 'Crossborder Crime Colloquium' as well as in other scientific events abroad (Manchester University, Tilburg). He has attended study and lecture tours at the Law Faculty of Charles University in Prague (2011), Max Planck Institute in Freiburg (2014, 2015, 2017), the University of Scranton in Pennsylvania, USA (2015), University of Salzburg (2016), Comillas University Pontificia, Madrid (2018), and other institutions. 
Gustáv Dianiška is a professor at the Faculty of Law of the Trnava University in Trnava (since 2000). He is head of the Department of Propedeutics of Legal Subjects and is involved in the activities of the Department of Criminal Law and Criminology. His courses on psychology to future lawyers include Social Psychology for Lawyers, Forensic Psychology and Criminology. He is a member of the Scientific Board of the Faculty of Law, a long-term member of the Slovak Psychological Society and its members.

Ondrej Hamul'ák is a senior lecturer in EU law at the Faculty of Law, Palacký University Olomouc and adjunct professor in EU law at Tallinn Law School. He completed master studies in law (2006) and PhD studies in law (2013) at the Faculty of Law in Olomouc. He is giving courses on EU law in law faculties in the Czech Republic, Slovakia and Estonia with a focus on EU constitutionalism. In his research, he focuses on EU constitutional law, human rights protection in the EU and cooperation in criminal matters within the EU.

Lukáš Turay graduated from the Faculty of Law of the Comenius University in Bratislava. During his studies, he undertook an internship at the Ministry of Justice of the Slovak Republic, the Supreme Court of the Slovak Republic and the District Prosecutor's Office Bratislava I. At present, he is an internal doctoral student at the Department of Criminal Law, Criminology and Criminalistics of the Faculty of Law, Comenius University in Bratislava. In his professional and scientific work, he focuses on criminal law and criminology. 